\title{
Genome-wide transcriptome and functional analysis of two contrasting genotypes reveals key genes for cadmium tolerance in barley
}

\author{
Fangbin Cao ${ }^{1}$, Fei Chen ${ }^{1}$, Hongyan Sun ${ }^{1}$, Guoping Zhang ${ }^{1}$, Zhong-Hua Chen ${ }^{2^{*}}$ and Feibo Wu ${ }^{{ }^{*}}$
}

\begin{abstract}
Background: Cadmium (Cd) is a severe detrimental environmental pollutant. To adapt to $\mathrm{Cd}$-induced deleterious effects, plants have evolved sophisticated defence mechanisms. In this study, a genome-wide transcriptome analysis was performed to identify the mechanisms of $\mathrm{Cd}$ tolerance using two barley genotypes with distinct $\mathrm{Cd}$ tolerance.

Results: Microarray expression profiling revealed that 91 genes were up-regulated by $\mathrm{Cd}$ in $\mathrm{Cd}$-tolerant genotype Weisuobuzhi and simultaneously down-regulated or non-changed in Cd-sensitive Dong 17, and 692 genes showed no change in Weisuobuzhi but down-regulated in Dong17. Novel genes that may play significant roles in Cd tolerance were mainly via generating protectants such as catalase against reactive oxygen species, $\mathrm{Cd}$ compartmentalization (e.g. phytochelatin-synthase and vacuolar ATPase), and defence response and DNA replication (e.g. chitinase and histones). Other 156 up-regulated genes in both genotypes also included those encoding proteins related to stress and defence responses, and metabolism-related genes involved in detoxification pathways. Meanwhile, biochemical and physiological analysis of enzyme (ATPase and chitinase), phytohormone (ethylene), ion distribution and transport $\left(\mathrm{Cd}, \mathrm{Na}^{+}, \mathrm{K}^{+}, \mathrm{Ca}^{2+}, \mathrm{ABC}\right.$ transporter) demonstrated that significantly larger $\mathrm{Cd}$-induced increases of those components in Weisuobuzhi than those in Dong17. In addition, Cd-induced DNA damage was more pronounced in Dong17 than that in Weisuobuzhi.
\end{abstract}

Conclusions: Our findings suggest that combining microarray, physiological and biochemical analysis has provided valuable insights towards a novel integrated molecular mechanism of $\mathrm{Cd}$ tolerance in barley. The higher expression genes in $\mathrm{Cd}$ tolerant genotype could be used for transgenic overexpression in sensitive genotypes of barley or other cereal crops for elevating tolerance to $\mathrm{Cd}$ stress.

Keywords: ATPase, Cadmium fluorescent indicator, Cadmium tolerance, Microarray, Hordeum vulgare L, Integrated molecular mechanism

\section{Background}

Cadmium (Cd) in soil represents a direct contact risk to both humans and ecological recipients due to its high toxicity and ready uptake by plants $[1,2]$. At present, $\mathrm{Cd}$ has become one of the most harmful and widespread pollutants in agricultural soils. This situation has resulted primarily from industrial emissions, application of $\mathrm{Cd}$ containing phosphate fertilisers and municipal waste disposal $[1,3]$. Once released into the soils, moderate $\mathrm{Cd}$

\footnotetext{
* Correspondence: z.chen@uws.edu.au; wufeibo@zju.edu.cn

${ }^{2} \mathrm{~S} c h$ ool of Science and Health, Hawkesbury Campus, University of Western Sydney, Locked Bag 1797, Penrith NSW 2751, Australia

'College of Agriculture and Biotechnology, Zijingang Campus, Zhejiang University, Hangzhou 310058, P.R. China
}

pollution could result in considerable $\mathrm{Cd}$ accumulation in edible parts of crops. Such levels of Cd not only affect the quality and yield of crops, but pose a great threat to human health [2]. Accordingly, these developments raise serious concerns for both the environment and human health. Therefore, there is an urgent need to elucidate the mechanisms of $\mathrm{Cd}$ tolerance in plants and to develop crop varieties with high $\mathrm{Cd}$ tolerance and yield.

$\mathrm{Cd}$ affects many important physiological processes and inhibits plant growth and development $[4,5]$. To minimise the detrimental effects of $\mathrm{Cd}$ toxicity, plants have evolved a range of detoxification mechanisms, including $\mathrm{Cd}$ exclusion, chelation and compartmentalisation in vacuoles [6]. For example, phytochelatins (PCs) and $\mathrm{Cd}$ 
have been found to form PC-Cd complexes in cytosol, which are subsequently transported into vacuoles. Thereby, it can protect plants from the deleterious effects of $\mathrm{Cd}$ [7]. The elevated expression of heavy metal transporting ATPases4 (HMA4) $\mathrm{P}_{1 \mathrm{~B}}$-type ATPase furnishes an efficient mechanism for increasing $\mathrm{Cd}$ tolerance in plants under $\mathrm{Cd}$ toxicity via the maintenance of low cellular $\mathrm{Cd}$ in the cytoplasm [8]. However, regulatory mechanisms in $\mathrm{Cd}$ tolerance, which is still a focal point in plant research, is a complex process that contains many genes regulated by a variety of physiological pathways [2].

Identification of stress-induced genes and proteins are fundamental in understanding the molecular mechanisms of stress responses and in developing transgenic plants with enhanced tolerance [9]. Studies have been conducted to identify plant defences against $\mathrm{Cd}$ toxicity and investigate $\mathrm{Cd}$-specific genes. For example, the up-regulation of well-known Cd-detoxifying proteins, such as phytochelatin synthase (PCS), antioxidative enzymes and glutathione S-transferases (GST), were observed in the response of plants to $\mathrm{Cd}$ stress using proteomic and metabolomic approaches [10]. Uraguchi and Fujiwara [2] summarised several Cd transport-related genes, such as OsLCT1, OsHMA, OsNramp1 and OsIRT1, involved in Cd transport and tolerance in rice. Despite the identification of those genes, the underlying knowledge of molecular mechanisms for plant Cd tolerance is still fragmental.

Knowledge about networks of global gene expression is imperative for further understanding the molecular mechanisms in plant $\mathrm{Cd}$ tolerance. Microarray analysis is a powerful technique for analysing the profiles of gene expression related to abiotic stress in plants $[11,12]$. Concerning $\mathrm{Cd}$ toxicity and detoxification in plants, the genome-wide transcriptome profiling has been explored mostly in herbaceous plants such as Arabidopsis thaliana, Arabidopsis halleri, and Thlaspi caerulescen [13-16]. However, the regulatory system for genes conferring Cd tolerance in many cereal crops is largely unknown and remains an essential issue to be addressed.

Barley, the fourth most important cereal in the world, is as an ideal model for genetic and physiological study [17]. Our previous studies have demonstrated distinctive genotypic difference between Cd-tolerant (Weisuobuzhi) and $\mathrm{Cd}$-sensitive (Dong17) genotypes in response to $\mathrm{Cd}$ stress including plant growth, photosynthesis, antioxidant enzyme activities $[1,18,19]$. We, therefore, hypothesised that there were large differences between the two genotypes in their genome-wide response to Cd stress. Candidate genes associated with $\mathrm{Cd}$ tolerance in the tolerant genotype were identified using the Affymertix barley GeneChip whole genome arrays, and the expression and enzyme activity of many key genes were further validated by quantitative real-time PCR (qRT-PCR) and physiological and biochemical analysis. We also proposed an integrated schematic diagram of the mechanisms involved in $\mathrm{Cd}$ tolerance and adaptation. These results are very important to provide novel clues for understanding the mechanisms in $\mathrm{Cd}$ tolerance of barley and open prospective for excavating novel genes and for the genetic improvement of plant tolerance to $\mathrm{Cd}$ stress.

\section{Methods}

Plant material, growth conditions and Cd treatments

A greenhouse hydroponic experiment was carried out at Huajiachi Campus of Zhejiang University, Hangzhou, China. Two barley genotypes, Cd-tolerant Weisuobuzhi and Cd-sensitive Dong17 [1], were used throughout the experiments.

Barley seeds were surface sterilised by soaking in $2 \%$ $\mathrm{H}_{2} \mathrm{O}_{2}$ for $30 \mathrm{~min}$ and fully rinsed with deionised water. After soaking in deionised water at room temperature for $4 \mathrm{~h}$, seeds were germinated in sterilised moist sand in an incubator at $22 \pm 1^{\circ} \mathrm{C}$. Ten-day-old healthy and uniform plants were selected and transplanted to 5-L containers filled with $4.5 \mathrm{~L}$ basal nutrient solution. The composition of nutrient solution was described by Chen et al. $[18,19]$. A week after transplanting, $\mathrm{Cd}$ (as $\mathrm{CdCl}_{2}$ ) was added to the corresponding containers to form 4 treatments: basal nutrient solution (control, without $\mathrm{Cd}$ ) and 5, 50 and $500 \mu \mathrm{M} \mathrm{Cd}$. The experiment was laid in a split-plot design with Cd-treatment as main-plot with six replicates. The nutrient solution was continuously aerated with pumps and renewed every $5 \mathrm{~d}$.

Plant samples were harvested $15 \mathrm{~d}$ after $\mathrm{Cd}$ treatment, and root tips were used for fluorescence imaging of $\mathrm{Cd}$. The second fully expanded leaves of control and $5 \mu \mathrm{M}$ $\mathrm{Cd}$ treatment were collected for microarray, physiological and biochemical analysis.

\section{Fluorescence imaging}

Fresh root tips were immersed in $20 \mathrm{mM}$ disodium ethylenediamine tetra-acetic acid ( $\mathrm{Na}_{2}$-EDTA) for $15 \mathrm{~min}$ and then gently rinsed for three times with deionised water. The specimen sections were then immediately immersed in the Cd probe Leadmium ${ }^{\mathrm{TM}}$ Green AM solution (Molecular Probes, Life Technologies, California, USA) for $45 \mathrm{~min}$ in the dark and then washed three times ( 5 min each time) with deionised water. A stock solution of Leadmium ${ }^{\text {т }}$ Green AM was made by adding $50 \mu \mathrm{L}$ of dimethyl sulfoxide (DMSO) to one vial of the dye. This stock solution was then diluted $1: 10$ with $0.85 \% \mathrm{NaCl}$. Roots were immersed in this solution for $90 \mathrm{~min}$ in the dark. The sections were examined with a laser confocal scanning microscope (Leica TCS SP5; Berlin, Germany) with excitation and emission wavelengths at 488 and $515 \mathrm{~nm}$, respectively. The fluorescence density of $\mathrm{Cd}$ was calculated by selecting the root sections and measuring the total Integrated 
Density using "Analyse and Measure" function of the Image J software (NIH, Bethesda, MD, USA).

\section{RNA isolation, probe preparation and microarray hybridisation}

Total RNA was initially extracted from leaf tissue of Weisuobuzhi and Dong17 under control and $5 \mu \mathrm{M} \mathrm{Cd}$ treatment using Trizol reagent protocol (P/N 15596-018, Life Technologies, Carlsbad, CA, USA). RNA was purified on RNeasy spin columns (RNeasy MinElute Cleanup Kit, Qiagen, Dusseldorf, Germany) and with on-column DNase1 treatment. The eluted total RNAs were quantified on an Agilent 2100 bioanalyser (Palo Alto, CA, USA) and adjusted to a final concentration of $1 \mu \mathrm{g} \mu \mathrm{L}^{-1}$. Sample processing, cDNA synthesis, biotin-labelled cRNA synthesis, hybridisation, washing, staining and scanning of Affymetrix Barley 1 GeneChip were performed following the standard protocol (Affymetrix Inc., Santa Clara, CA, USA). The Barley 1.0 Affymetrix microarray GeneChip array consists of 22,795 probe sets designed from an exemplar set of barley sequences derived from 350,000 highquality expressed sequence tag (EST) contigs. Total RNA was used to prepare double strand cDNA. Labelled cRNA preparation and hybridisation on GeneChip and scanning was done following the standard Affymetrix procedures (http://media.affymetrix.com/support/downloads/manuals/ 3_ivt_express_kit_manual.pdf). Three replications of each sample were conducted to test the quality and reproducibility of the chip hybridisation. Each treatment had three replications.

\section{Microarray data analysis}

Data analysis was conducted using Refiner and Analyst, two analytical tools in Affymetrix GeneChip Operating Software Version 1.4. The Refiner tool condenses and normalises the raw signal. The Analyst tool provides statistical analysis and data visualisation capability. Detection, signal condensation and normalisation were conducted using Robust Multichip Analysis (RMA) of the Refiner tool [20]. Further analysis of transcript abundance was conducted using the Analyst tool. The correlation of expression signals between replications for each genotype was 0-0.99 across all probe sets tested on the GeneChip. Each Barley1.0 GeneChip probe set was first tested for barley transcript specificity on the basis of quantitative and qualitative transcript abundance differences between barley genotype Betzes and wheat cultivar Chinese Spring (CS).

To detect barley transcripts in the two lines (Weisuobuzhi and Dong17), differences in the abundance of barley transcript signals in the two lines were tested against the background signal in CS with a $t$-test $(P$-value $<0.001)$. Only those showing significantly higher transcript levels both in Betzes and in the two lines compared to those in CS were subjected to qualitative analysis to detect barley- specific transcripts in the two lines (presence/absence test, $P<0.001$ using MAS 5.0). All data from the Affymetrix scanner have been deposited at BarleyBase (http://www. barleybase.org) in the form of DAT, CEL, EXP, and CHP files. We considered a change of at least two folds as an indication of a significant change in gene expression for up- and down-regulation. To perform hierarchical clustering, the differentially regulated genes were clustered according to similarities in expression profiles. The following nine groups were used: Weisuobuzhi (W) up-regulated and Dong17 (D) down-regulated (Group I) or no change (Group II), W no change and D downregulated (Group III), both up-regulated (Group IV), W down-regulated and D up-regulated (Group V), both down-regulated (Group VI), W down-regulated and D no change (Group VII), W no change and D up-regulated (Group VIII), and both no change (Group IX).

\section{qRT-PCR}

The hydroponic experiment was carried once again using Weisuobuzhi and Dong17 under control and $5 \mu \mathrm{M} \mathrm{Cd}$ treatment with four replicates. Total RNA was isolated from leaves after 15 days of $\mathrm{Cd}$ treatment using the TRIzol reagent (Invitrogen, Karlsruhe, Germany). Residual DNA was removed using purifying columns. One microgram of each RNA sample was subsequently employed for cDNA synthesis with $0.5 \mu \mathrm{g}$ of oligo (dT) $12-18$ and 200 units of Superscript II (Invitrogen, Karlsruhe, Germany). cDNA samples used for GeneChip analysis and this experiment were assayed by quantitative real time PCR (qRT-PCR) in an $\mathrm{iCycler}_{\mathrm{iQ}} \mathrm{Q}^{\mathrm{Ts}}$ Real-time PCR Detection System (Bio-Rad, Hercules, CA, USA) using the SYBR Green PCR Master Mix (Applied Biosystems, Life Technologies, CA, USA). The PCR conditions consisted of denaturation at $95^{\circ} \mathrm{C}$ for $3 \mathrm{~min}$, followed by 40 cycles of denaturation at $94^{\circ} \mathrm{C}$ for $1 \mathrm{~min}$, annealing at $58^{\circ} \mathrm{C}$ for $30 \mathrm{~s}$ and extension at $72^{\circ} \mathrm{C}$ for $30 \mathrm{~s}$, and continued extension at $72^{\circ} \mathrm{C}$ for $5 \mathrm{~min}$. The barley ACTIN (accession no. AY145451) was used as a reference gene, which were selected from a number of candidates by Chen et al. [18,19]. The primers are listed in Additional file 1: Table S1. Two independent experiments and six biological replications in total were conducted.

\section{Enzyme activity measurements}

For the determination of GST (EC 2.5.1.18) and ATPase (EC 3.6.1.3) activities, plant tissue was homogenised in $8 \mathrm{ml} 50 \mathrm{mM}$ sodium phosphate buffer (PBS, pH 7.8,) using a pre-chilled mortar and pestle, then centrifuged at $10000 \times \mathrm{g}$ for $20 \mathrm{~min}$ at $4^{\circ} \mathrm{C}$. The supernatant was used for enzyme assay. GST and ATPase activities were determined with an enzyme assay kit according to the manufacturers' protocol (Jiancheng Bio Co., Nanjing, China). Chitinase (EC 3.2.1.14) were extracted and determined with an ELISA kit according to the 
manufacturers' protocol (Becton, Dickinson and Company, FranklinLakes, NJ, USA).

\section{Determination of DNA damage}

DNA damage was assayed according to Menke et al. [21] with minor modification. The experiment was performed in a darkroom with dim red light. About $150 \mathrm{mg}$ leaf samples were sliced in $1 \mathrm{~mL}$ PBS buffer $(160 \mathrm{mM} \mathrm{NaCl}, 8 \mathrm{mM}$ $\mathrm{Na}_{2} \mathrm{HPO}_{4}, 4 \mathrm{mM} \mathrm{NaH} \mathrm{PO}_{4}, \mathrm{pH}$ 7) containing $50 \mathrm{mM}$ EDTA on ice with a fresh razor blade. The $30 \mu \mathrm{L}$ suspension was then taken on regularly used microscopic slides (pre-coated with $1 \%$ of agarose in double distilled $\mathrm{H}_{2} \mathrm{O}$ and dried over night at room temperature) followed by addition of $30 \mu \mathrm{L} 1 \%$ agarose solution $\left(42^{\circ} \mathrm{C}\right)$. DNA damage was analysed by the comet assay according to the alkali-alkali (A/A) method as described by Menke et al. [21]. For comet assay, unwinding was done in high alkali for $5 \mathrm{~min}$, and then electrophoresis for $10 \mathrm{~min}$ with $21 \mathrm{~V}$, $300 \mathrm{~mA}$ in a chamber cooled on ice, followed by a short neutralisation of $3 \mathrm{~min}$ in $100 \mathrm{mM}$ Tris- $\mathrm{HCl}$ (pH 7.5). To remove the starch grains, the slides were kept for $10 \mathrm{~min}$ in $1 \%$ Triton prior to dehydration in $70 \%$ ( $2 \mathrm{~min}$ ) and $96 \%$ (5 min) ethanol and air-drying. The gels were then stained with $15 \mu \mathrm{L}$ ethidium bromide $\left(5 \mu \mathrm{g} \mathrm{ml}^{-1}\right)$ and immediately used for evaluation. Images were taken using a fluorescence microscope (BX50WI, Olympus, Japan) equipped with a digital CCD camera (Olympus, Japan).

\section{Gas chromatography}

Ethylene production in the leaves of barley seedling was measured as described by Chen et al. [22] with minor modification. In brief, leaf tissues ( $0.5 \mathrm{~g}$ fresh weight) were collected, immediately weighed, and then placed in sealed glass vials containing water-saturated filter paper. Samples were incubated for $1 \mathrm{~h}$ under illumination. One millilitre of gas was collected using a gas-tight syringe and injected into a gas chromatography (Focus GC, Thermo Fisher Scientific, MA, USA) equipped with a capillary column (CP-carboPLOT P7, Varian, CA, USA) and flameionisation detector for ethylene determination. Ethylene production was calculated on the basis of known ethylene standards and leaf fresh weight.

\section{Leaf element analysis}

Leaf samples were dried at $80^{\circ} \mathrm{C}$, digested with $\mathrm{HNO}_{3} /$ $\mathrm{HClO}_{4}(4: 1, \mathrm{v} / \mathrm{v})$ for $3 \mathrm{~h}$, and then diluted to $25 \mathrm{ml}$ by adding de-ionized water. Calcium $\left(\mathrm{Ca}^{2+}\right)$, sodium $\left(\mathrm{Na}^{+}\right)$, and potassium $\left(\mathrm{K}^{+}\right)$concentrations were determined using an Inductively Coupled Plasma Optical Emission Spectrometer (ICP-OES, Optima 8000DV, PerkinElmer, USA).

\section{Statistical analysis}

All data are the averages of three to six biological replicates in each experiment. Statistical analyses were performed with Data Processing System (DPS) statistical software. An ANOVA followed by a Duncan's multiple range test (DMRT) were used to evaluate treatment effects at significance level of $P<0.05$.

\section{Results}

\section{Cd is highly accumulated in root tips of a Cd-tolerant genotype}

Under Cd stress, the majority of Cd accumulated in root cell wall. In root tips of Weisuobuzhi treated with $5 \mu \mathrm{M}$ $\mathrm{Cd}$, preferential localisation of $\mathrm{Cd}$ was in root apex, and this effect was more pronounced with increasing Cd levels (Figure 1A and $1 \mathrm{C}$ ). However, there were no noticeable and only very low levels of green fluorescence in the root tips of Dong17 under 5 and $50 \mu \mathrm{M} \mathrm{Cd}$, respectively (Figure $1 \mathrm{~A}$ and $1 \mathrm{C}$ ). Higher fluorescence intensity was observed in $500 \mu \mathrm{M}$ Cd treatment in Dong17, which was similar to that of Weisuobuzhi. The cross section fluorescence images revealed that after Cd stress, most $\mathrm{Cd}$ accumulated in the inner epidermis and endodermis, with only a small amount of $\mathrm{Cd}$ in the cortex. In response to $500 \mu \mathrm{M} \mathrm{Cd}$, an intense green fluorescence was observed in the epidermal, cortical and stele cells of Weisuobuzhi but not in Dong17 (Figure 1B and 1D).

\section{Cd toxicity induces large scale changes in gene expression}

The distinct cellular Cd accumulation pattern (Figure 1) and tolerance $[18,19]$ of the two genotypes has led us to explore the expression pattern of their $\mathrm{Cd}$-induced genes. The microarray data showed that, compared with control, the gene expression profiles of the two genotypes changed significantly after exposing to $5 \mu \mathrm{M} \mathrm{Cd}$ for $15 \mathrm{~d}$. Based on at least \pm 2.0 -fold changes $(P<0.05)$, a total of 1,750 genes were differentially expressed between $\mathrm{Cd}$-stressed and control plants. Of these genes, only 247 and 103 genes were up- and down-regulated in Weisuobuzhi, while there were 3.6- (898) and 6.9-fold (710) more genes upregulated and down-regulated in Dong17, respectively (Additional file 2: Figure S1 and Additional file 3: Table S2).

Further comparing the transcriptome responses to $\mathrm{Cd}$ stress between the two genotypes, these 1,750 differentially regulated genes were classified into eight groups (Additional file 3: Table S2). The genes in Group I and Group II were highly induced by Cd only in Weisuobuzhi (Figure 2, Additional file 4: Table S3 and Additional file 5: Table S4). Genes in Group III showed no change in Weisuobuzhi and were down-regulated in Dong17 (Additional file 6: Table S5). Group IV represented 156 genes that showed up-regulated expression patterns in both genotypes (Additional file 7: Table S6). The genes in Groups V, VI and VII were down-regulated in Weisuobuzhi (Additional file 8: Table S7, Additional file 9: Table S8 and Additional file 10: Table S9). The genes in 
(A)
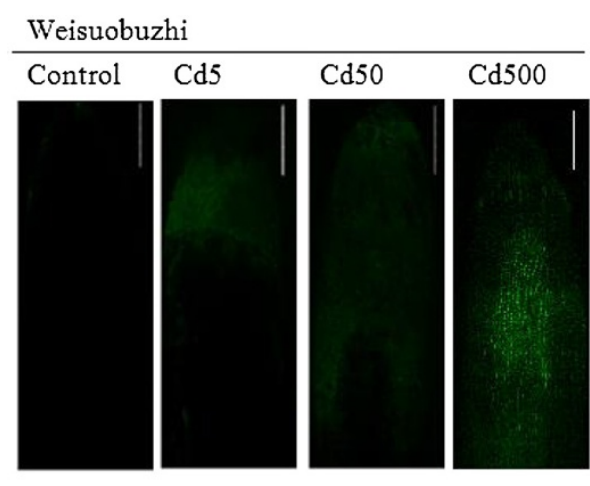

Dong17

(B)

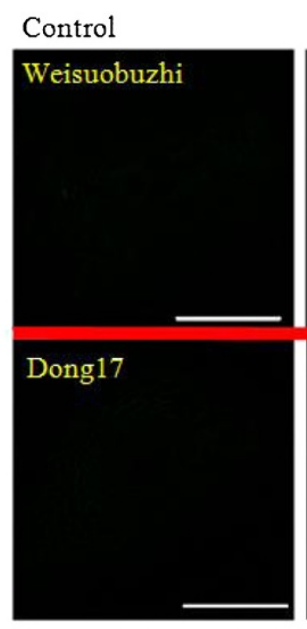

$\mathrm{Cd} 5$

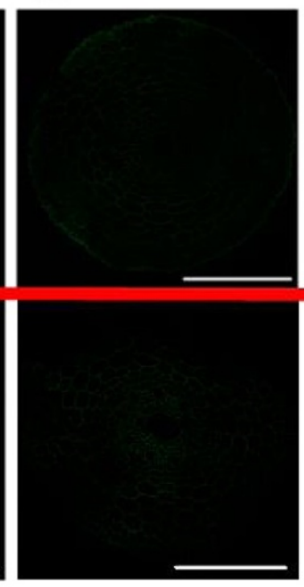

$\mathrm{Cd} 50$
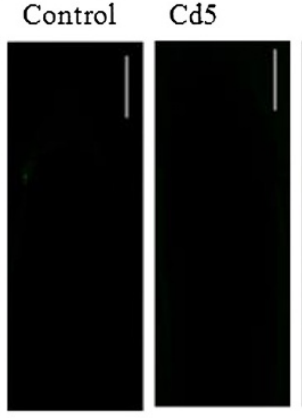

$\mathrm{Cd} 50$

$\mathrm{Cd} 500$
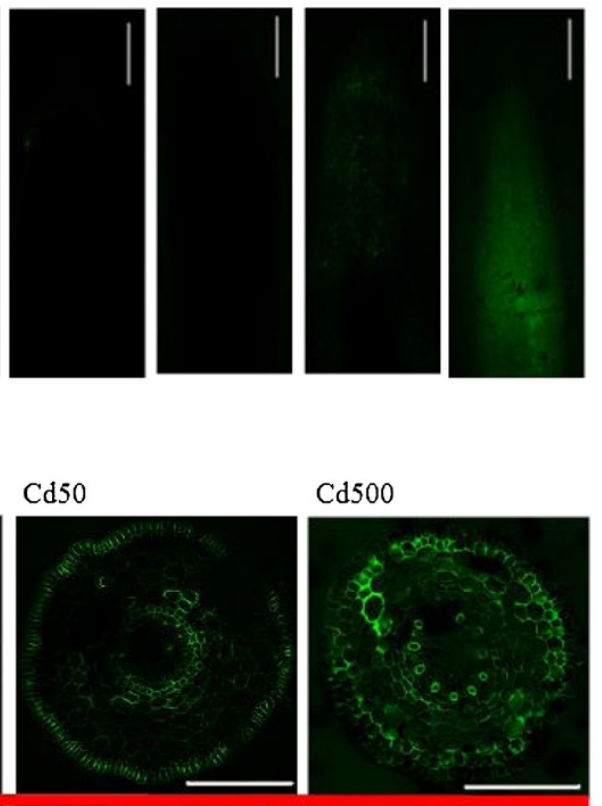

Cd500
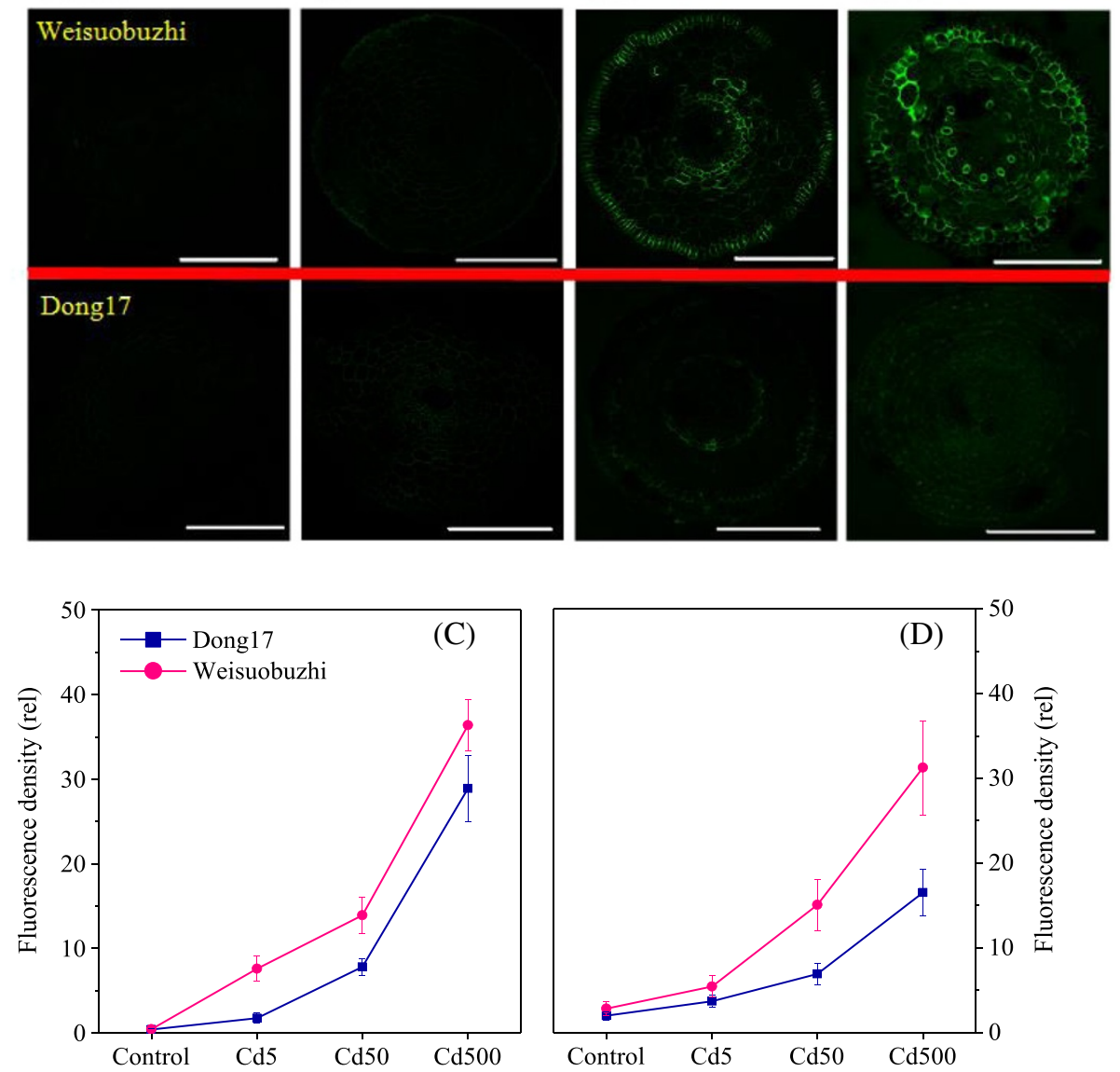

Figure 1 Cellular localisation of $\mathbf{C d}^{\mathbf{2 +}}$ in barley roots. Barley roots were exposed to 0,5,50 and $500 \mu \mathrm{M}$ Cd for 15 days before staining with Leadamium ${ }^{\text {TM }}$ Green AM. Representative micrographs show the binding of $\mathrm{Cd}^{2+}$ to Leadamium ${ }^{\mathrm{TM}} \mathrm{Green}$ AM dye at longitudinal (A) and $\mathrm{Cross}$ (B) section of root tips of barley genotypes Weisuobuzhi and Dong17. Scale bars $=250 \mu \mathrm{m}$. Line graphs show relative Cd ${ }^{2+}$ fluorescence density from longitudinal (C) and cross (D) section of root tips. Data are means \pm SD $(n=3)$.

Group VIII were un-regulated in Weisuobuzhi but upregulated in Dong17 (Additional file 11: Table S10).

Here, we focused on the genes in Groups I, II and III, which are more likely to play crucial roles for $\mathrm{Cd}$ tolerance in barley. Along with these differentially regulated genes related to stress and defence responses, there were also functional genes encoding a number of carbohydrate metabolism related proteins and several transcription factors, along with a diverse set of enzymes and transporters (Figure 3; Additional file 12: Figure S2, 


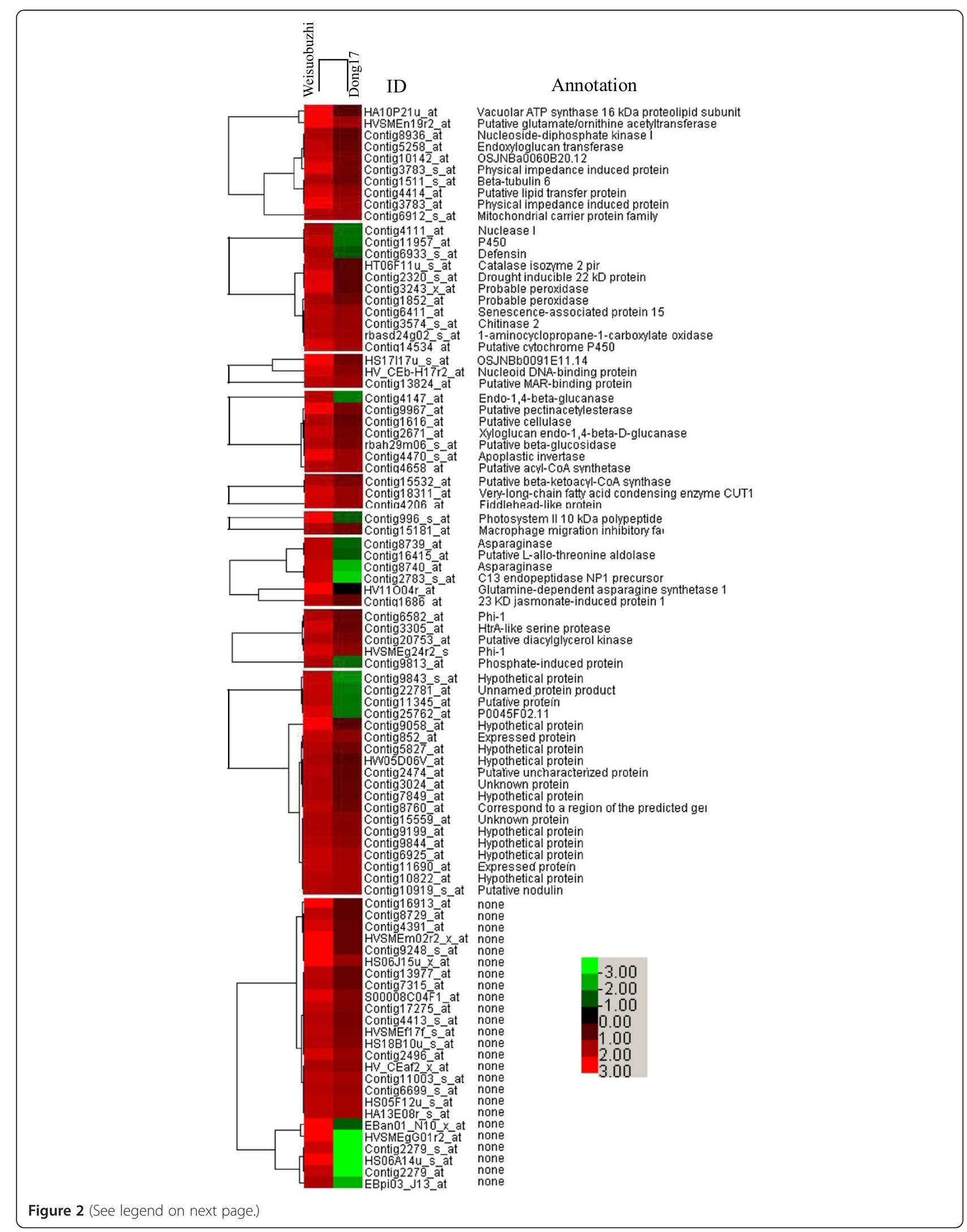


(See figure on previous page.)

Figure $\mathbf{2}$ Cd-induced differential gene expression in leaves of two barley genotypes. Heat map visualises the expression of genes up-regulated in Weisuobuzhi and down-regulated and not changed in Dong17 (Cd vs control) after Cd exposure for $15 \mathrm{~d}$. The contig IDs and annotations are listed on the right. Red, green and black indicate genes that increased, decreased and showed equal levels of expression, respectively, as compared to the control. The contig ID and annotation of each gene are listed on the right of the figure. The identity and accession numbers of genes are listed in Additional file 4: Table S3 and Additional file 5: Table S4.

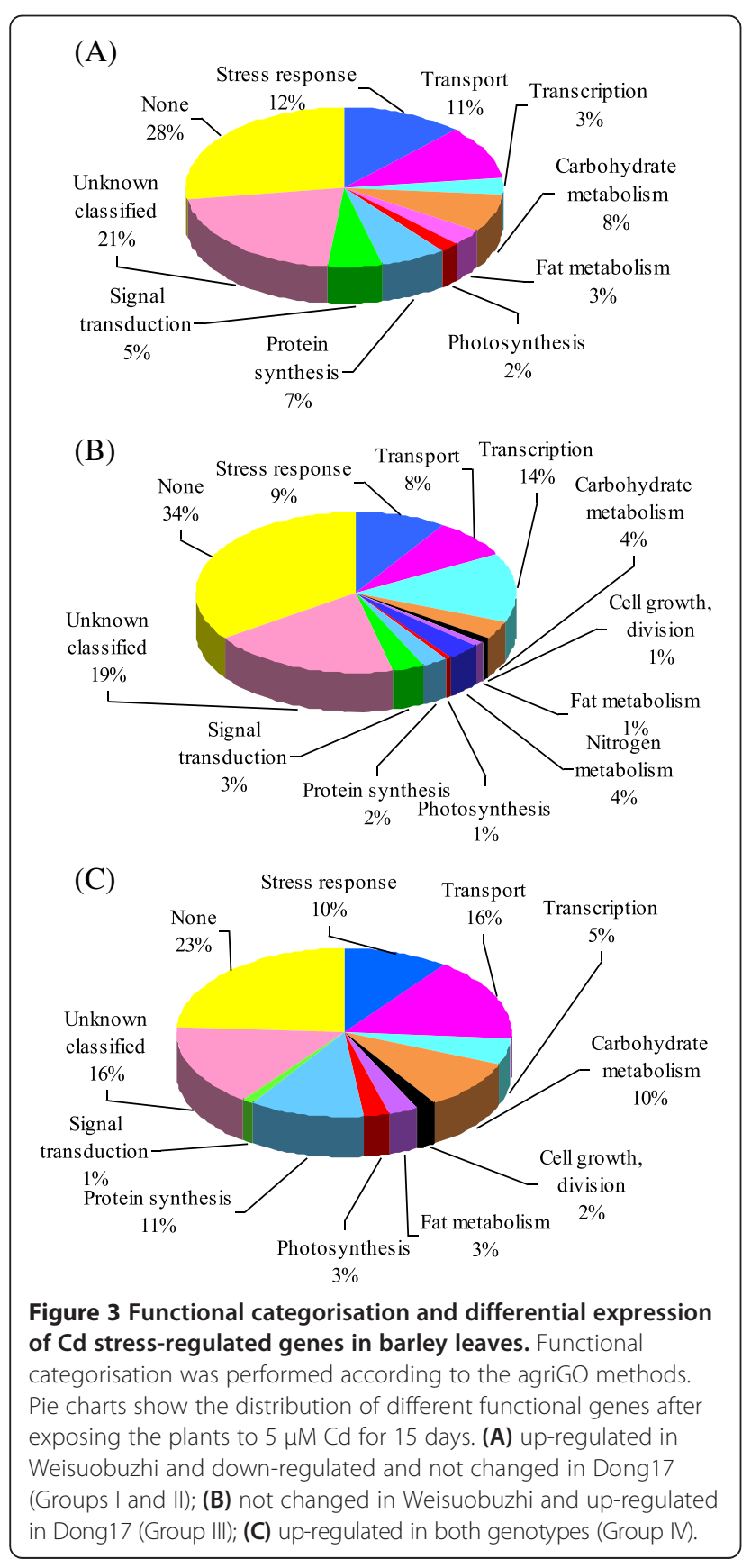

Additional file 3: Table S2, Additional file 4: Table S3, Additional file 5: Table S4, Additional file 6: Table S5, Additional file 7: Table S6, Additional file 8: Table S7, Additional file 9: Table S8, Additional file 10: Table S9 and Additional file 11: Table S10). Therefore, functional categorisation of these genes may provide clues to the understanding of physiological and molecular mechanisms involved in $\mathrm{Cd}$ stress response. The data pertinent to $\mathrm{Cd}$ tolerance were presented in the following sections (Additional file 4: Table S3, Additional file 5: Table S4 and Additional file 6: Table S5).

\section{Key genes for $\mathrm{Cd}$ tolerance are highly expressed only in the Cd-tolerant genotype}

These genes were up-regulated in Cd-tolerant genotype Weisuobuzhi (W-up) and down- (D-down) or un-regulated (D-none) in Cd sensitive genotype Dong17 (Additional file 4: Table S3 to Additional file 5: Table S4, Figure 3A). Group I included 7 genes encoding key enzymes for nitrogen catabolism such as asparaginase and C13 endopeptidase NP1 precursor. The 84 genes in Group II were upregulated after $\mathrm{Cd}$ treatment in Weisuobuzhi but showed no change in Dong17 (Additional file 5: Table S4). Of these, there were 6 signal transduction related genes (e.g. the gene encoding $23 \mathrm{KD}$ jasmonate-induced protein 1), 11 stress and defence response related genes (such as the genes encoding catalase isozyme 2 , peroxidase, and chitinase 2), 10 carbohydrate and fat metabolism related genes (e.g. the gene encoding acetyl-CoA synthetase). Additionally, the expression of 10 transporter genes (e. g. the genes encoding vacuolar ATP synthase, $16 \mathrm{kDa}$ proteolipid subunit and putative lipid transfer protein) under Cd stress was up-regulated in Weisuobuzhi but showed no change in Dong17.

\section{Key genes for Cd-tolerance are down-regulated only in} the Cd-sensitive genotype

The majority of the 692 genes in Group III were responsible for stress and defence response, transport, transcription and signal transduction (Additional file 6: Table S5, Figure 3B). For instance, the salicylic acid (SA), jasmonate (JA), ethylene (ET) and $\mathrm{Ca}^{2+}$ induced genes were all significantly down-regulated in Cd-sensitive genotype Dong17, but were not affected in Weisuobuzhi after $15 \mathrm{~d}$ of Cd exposure, with the exception of a $23 \mathrm{kDa}$ JA-induced protein that was up-regulated in Weisuobuzhi (Additional file 5: Table S4 and Additional file 6: Table S5). There were 2 
isoforms of GST showing differential expression in both genotypes (Additional file 6: Table S5). Genes encoding nitrate (NRaT) and nitrite (NRiT) transporters, as well as a gene encoding dehydrins (late embryogenesis abundant, LEA) were down-regulated in Dong17 but remained unchanged in Weisuobuzhi. Heat shock proteins (HSPs) were highly down-regulated under Cd stress in Dong17.

\section{qRT-PCR confirms expression pattern of the microarray}

The expression data obtained from microarray analysis was further confirmed using qRT-PCR. The expression profile of eleven differentially expressed genes that were related to $\mathrm{Cd}$ tolerance in the two genotypes is shown in Figure 4. The expression patterns were similar, although the qRT-PCR-based relative expression of those genes did not exactly match the fold changes found in the microarray analysis.

\section{Biochemical and physiological validation of the roles of key genes in Cd tolerance}

To test whether the higher levels of transcripts in Weisuobuzhi are linked to Cd tolerance in barley, we conducted a series of assays on enzyme activity (Figure 5, Table 1), DNA damage (Figure 6), ethylene emission (Table 1) and essential nutrients (Table 2). Overall, the microarray and qRT-PCR data were in good agreement with these biochemical and physiological results.

In comparison to the control, $\mathrm{Cd}$ stress resulted in significant increases in the activity of $\mathrm{H}^{+}-, \mathrm{Na}^{+} \mathrm{K}^{+}-, \mathrm{Ca}^{2+} \mathrm{Mg}^{2+}-$ and total-ATPase of $217 \%, 140 \%, 104 \%$, and $143 \%$ in Weisuobuzhi, but those numbers were only $80 \%, 74 \%$, $69 \%$ and $72 \%$ for Dong17, respectively (Figure 5).
Moreover, Cd stress caused a $110 \%$ increase in GST activity in Weisuobuzhi but no statistically significant change was observed in Dong17 (Table 1). The significant increase of chitinase activity under Cd stress was 1.7fold higher in Weisuobuzhi than that in Dong17 (Table 1).

DNA appeared as densely condensed structured resembling a bead and no DNA damage was observed in both genotypes in the control (Figure 6). However, Cd stress induced a marked increase in DNA damage in the Cd-sensitive genotype Dong17. Moreover, Cd stress led to a significant increase in ethylene emission in both genotypes. However, the rate of ethylene emission was significant higher in Weisuobuzhi than that in Dong17 (Table 1).

$\mathrm{Cd}$ treatment resulted in a significant decrease of leaf $\mathrm{Ca}^{2+}$ concentration, which was 2.0-fold higher for Dong17 in contrast to Weisuobuzhi. Cd stress caused an 11.0\% decrease of $\mathrm{K}^{+}$content in Dong17, but no significant difference was observed in Weisuobuzhi. Surprisingly, $\mathrm{Na}^{+}$content was also markedly reduced under Cd stress in both genotypes (Table 2).

\section{Discussion}

\section{Comparative transcriptome analysis reveals key genes} associated with $\mathrm{Cd}$ tolerance

In barley, no molecular evaluation of $\mathrm{Cd}$ tolerance mechanisms has been fully explored so far. This study used large-scale transcript profiling to examine cellular processes affected by $\mathrm{Cd}$ stress in leaves of Cd-tolerant Weisuobuzhi and Cd-sensitive Dong17. A number of key genes have been shown to be induced or repressed differently in the two contrasting barley genotypes under
(A)

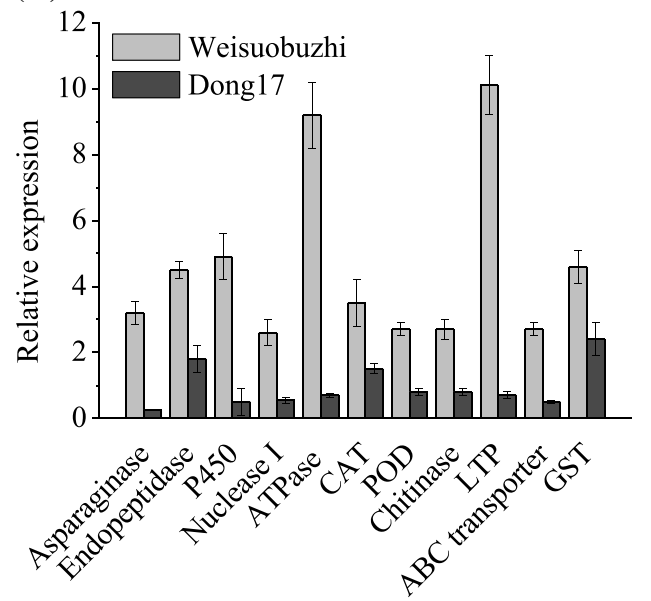

(B)

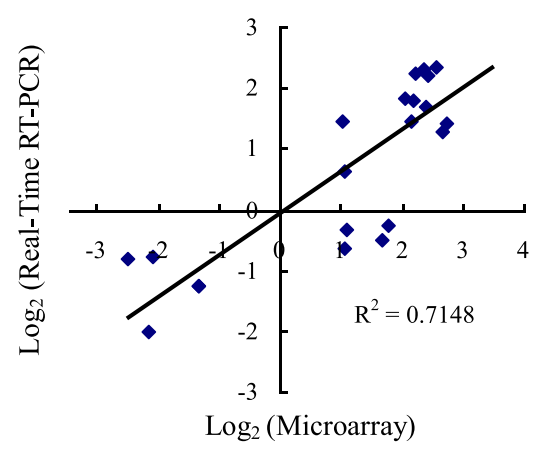

Figure 4 Quantitative RT-PCR validations of microarray data of Cd-responsive key genes in barley leaves. (A) The values represents the gene expression in $5 \mu \mathrm{M}$ Cd over those in the control in Weisuobuzhi (grey bars) and Dong 17 (black bars) ( $\mathrm{n}=6$ biological replicates). ACTIN was used as the reference gene. (B) Data plotted are the mean ratio of gene expression in Cd treatment (5 $\mu \mathrm{M} \mathrm{Cd}$ for $15 \mathrm{~d}$ ) over those in the control in the two genotypes on a log2 scale $\left(r^{2}=0.7148 ; P<0.001\right)$. CAT, catalase isozyme; POD, peroxidase; P450, cytochrome P450; LTP, lipid transfer protein and GST, glutathione transferase. 


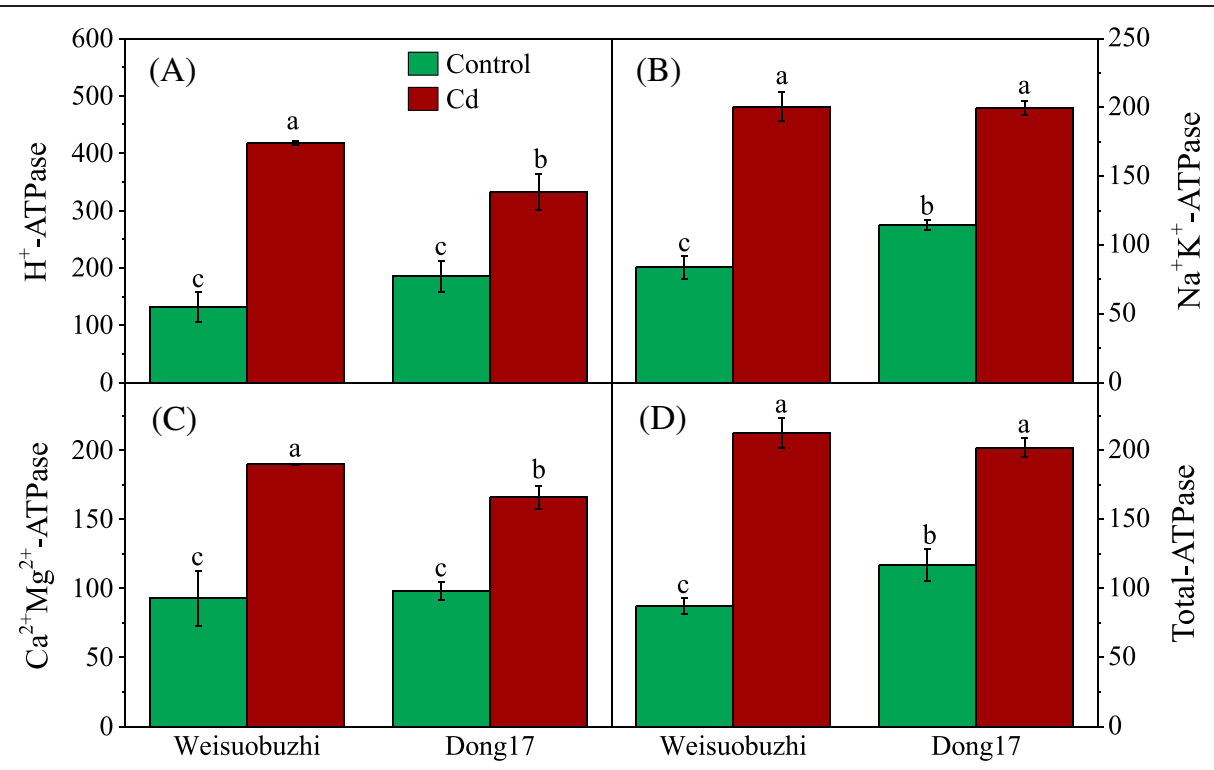

Figure 5 Comparison of ATPase activity in leaves of two barley genotypes. $\mathrm{H}^{+}-\mathrm{ATPase}(\mathrm{A}), \mathrm{Na}^{+} \mathrm{K}^{+}-\mathrm{ATPase}$ (B), $\mathrm{Ca}^{2+} \mathrm{Mg}^{2+}-\mathrm{ATPase}(\mathrm{C})$, and total ATPase (D) of Weisuobuzhi and Dong17 were measured in the control and after $15 \mathrm{~d}$ of $5 \mu \mathrm{M} \mathrm{Cd}$ treatment. Data are means \pm SD $(n=4)$. The value of total-ATPase activity is not the sum of all ATPase activities due to different methods used in the assay. Different lowercase letters in each graph indicate significant differences at $P<0.05$.

Cd stress. Based on these identified Cd-responsive genes, we propose an integrated schematic diagram of the mechanisms involved in Cd tolerance and adaptation (Figure 7) and a specific model for compartmentalization (Additional file 13: Figure S3), which may provide novel clues towards the characterisation of molecular mechanisms underlying $\mathrm{Cd}$ tolerance in barley.

\section{Detoxification genes are largely responsible for $\mathrm{Cd}$ tolerance in barley}

One aspect of $\mathrm{Cd}$ tolerance and adaptation is the ability to scavenge Cd-induced reactive oxygen species (ROS) in order to protect membranes and other macromolecules [3]. Antioxidant enzymes, such as catalase (CAT) and

Table 1 Effects of $15 \mathrm{~d}$ of $\mathrm{Cd}$ treatment on ethylene emission and the activities of glutathione S-transferases (GST) and chitinase in leaves of two barley genotypes

\begin{tabular}{|c|c|c|c|}
\hline Treatment & 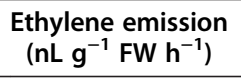 & $\begin{array}{c}\text { GST } \\
\text { (unit } \mathrm{g}^{-1} \mathrm{FW} \text { ) }\end{array}$ & $\begin{array}{c}\text { Chitinase } \\
\text { (unit } \mathrm{g}^{-1} \mathrm{FW} \text { ) }\end{array}$ \\
\hline \multicolumn{4}{|l|}{ Weisuobuzhi } \\
\hline Control & $0.042 c$ & $95.2 b$ & $172.1 \mathrm{c}$ \\
\hline \multirow[t]{2}{*}{$5 \mu \mathrm{M} \mathrm{Cd}$} & $1.136 a$ & $200.1 a$ & $218.1 a$ \\
\hline & $(+35.6 \%)^{*}$ & $(+4.2 \%)$ & $(+16.1)$ \\
\hline \multicolumn{4}{|l|}{ Dong17 } \\
\hline Control & $0.019 c$ & $210.8 a$ & $162.3 c$ \\
\hline $5 \mu \mathrm{M} \mathrm{Cd}$ & $0.838 b$ & 192.0a & $187.8 b$ \\
\hline
\end{tabular}

$\overline{\text { FW, fresh weight; Different lowercase letters indicate significant difference }}$ at $P<0.05$ level $(n=4) .{ }^{*}$, relative increase $(+)$ percentage calculated by 100 *(Weisuobuzhi-Dong17)/Dong17 under Cd stress.
CuZn-superoxide dismutase (SOD), play key roles in scavenging ROS under heavy metal stress [23]. GST includes a family of potent detoxification enzymes, and is thought to contribute to the primary cellular defence against oxidative stress [24]. In this study, the expression levels of the genes encoding CAT2 and CuZn-

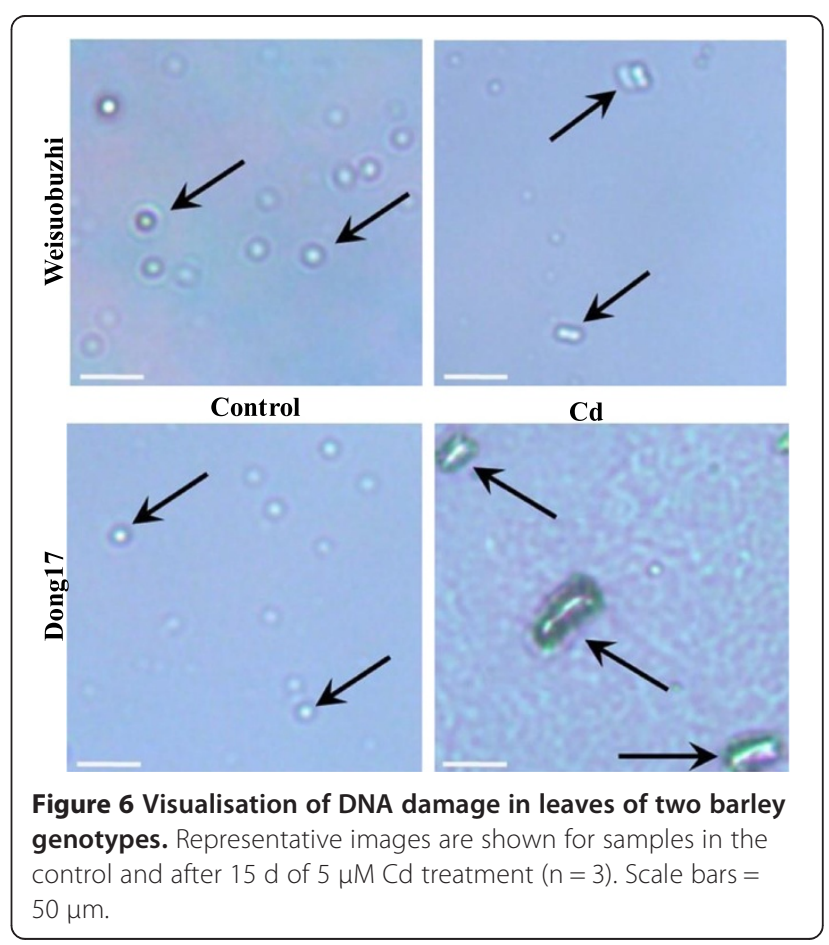


Table 2 Effects of $15 \mathrm{~d}$ of $\mathrm{Cd}$ treatment on $\mathrm{Ca}^{2+}, \mathrm{Na}^{+}$, and $\mathrm{K}^{+}$content in leaves of two barley genotypes

\begin{tabular}{|c|c|c|c|c|}
\hline Treatment & $\mathrm{Ca}^{2+}\left(\mathrm{g} \mathrm{kg}^{-1} \mathrm{DW}\right)$ & $\mathrm{Na}^{+}\left(\mathrm{g} \mathrm{kg}^{-1} \mathrm{DW}\right)$ & $\mathrm{K}^{+}\left(\mathrm{g} \mathrm{kg}^{-1} \mathrm{DW}\right)$ & $\mathrm{Na}^{+} / \mathrm{K}^{+}(\%)$ \\
\hline \multicolumn{5}{|c|}{ Weisuobuzhi } \\
\hline Control & $6.30 \mathrm{a}$ & $1.76 b$ & $89.4 a b$ & $1.97 b$ \\
\hline \multirow[t]{2}{*}{$5 \mu \mathrm{M} \mathrm{Cd}$} & $5.55 b$ & $1.23 d$ & $86.8 b$ & $1.42 \mathrm{C}$ \\
\hline & $(+18.3 \%)^{*}$ & $(-18.0 \%)$ & $(+7.2 \%)$ & $(-23.6 \%)$ \\
\hline \multicolumn{5}{|l|}{ Dong17 } \\
\hline Control & $6.16 a b$ & $2.08 a$ & $91.0 \mathrm{a}$ & $2.29 a$ \\
\hline $5 \mu \mathrm{M} \mathrm{Cd}$ & $4.69 c$ & $1.50 c$ & $81.0 c$ & $1.86 b$ \\
\hline
\end{tabular}

DW, dry weight; Different lowercase letters in each column indicate significant difference at $P<0.05$ level $(n=4) . *$, relative increase $(+) /$ reduction $(-)$ percentage calculated by $100 *$ (Weisuobuzhi-Dong17)/Dong17 under Cd stress.

SOD confirmed the higher enzyme activity in Weisuobuzhi in our previous publication [19]. Also, higher transcripts of GST found in both microarray and qRTPCR were matched by a significantly elevated GST activity in Weisuobuzhi as compared to a small decrease in Dong17 (Table 1; Figure 4; Additional file 5: Table S4 and Additional file 6: Table S5). As a result, Dong17 accumulated more $\mathrm{O}_{2}, \mathrm{H}_{2} \mathrm{O}_{2}$ and MDA than Weisuobuzhi [19].

Membrane bound enzyme ATPases provide energy and an $\mathrm{H}^{+}$gradient for the co-transport of copper, cobalt, lead, and $\mathrm{Cd}$ with protons for the detoxification of these metal ions in plants [25,26]. Cation antiporter activity driven by vacuolar ATPase-dependent proton motive force contributes significantly to the detoxification of $\mathrm{Cd}$ via vacuolar compartmentalisation in plants [27]. In this study, transcripts of V-ATPase were significantly elevated in Weisuobuzhi but showed no change in Dong17 (Additional file 5: Table S4). In addition, we validated the microarray data using biochemical analysis with significantly higher $\mathrm{Cd}$-induced $\mathrm{H}^{+}$, and $\mathrm{Ca}^{2+} \mathrm{Mg}^{2+}$-ATPase and much larger $\mathrm{Cd}$-induced increase in $\mathrm{Na}^{+} \mathrm{K}^{+}$- and total-ATPase activities in Weisuobuzhi (Figure 5).

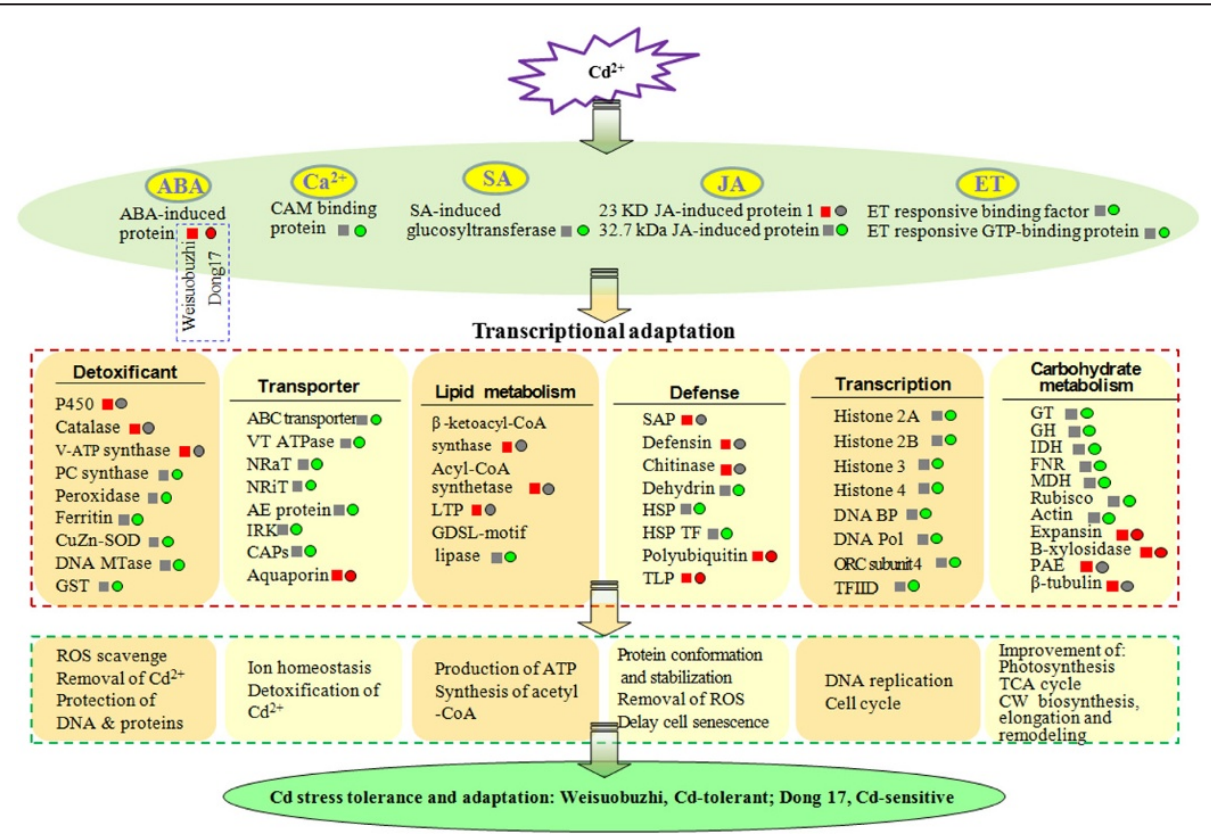

Figure 7 Integrated schematic diagram of the mechanisms involved in Cd tolerance in barley. Genes labelled with red, grey and green squares (Weisuobuzhi) circles (Dong17) are up-regulated, not changed and down-regulated by $5 \mu \mathrm{M} C \mathrm{C}$ treatment, respectively. ABA, Abscisic acid; AE protein, Anion exchange protein; CAPs, Clathrin-associated protein; CAM, calmodulin; CAT; Catalase isozyme 2; CW, Cell wall; DNA BP, DNA binding protein; DNA MTase, DNA methyltransferase; DNA Pol, DNA polymerase; ET, Ethylene; FNR, Ferredoxin NADP(H) oxidoreductases; GH, Glycosyl hydrolase; GST, Glutathione transferase; GT, Glycosyl transferase; HSP, Heat shock protein; HSP TF, Heat shock transcription factor; IDH, Isocitrate dehydrogenase; IRK, Inwardly rectifying potassium channel; JA, jasmonate; LTP, Lipid transfer protein; MDH, Malate-dehydrogenase; NRaT, Nitrate transporter; NRiT, Nitrite transport protein; ORC subunit 4, Origin recognition complex subunit 4; PAE, Pectinacetylesterase; PC, phytochelatin; SA, Salicylate; SAP, Senescence-associated protein; TFIID, Transcription initiation Factor TFIID; TLP, Thaumatin-like proteins; V-ATP synthase, Vacuolar ATP synthase; VT ATPase, Vesicle transfer ATPase. 
DNA methylation is an important modification of DNA that plays a key role in gene regulation, DNA replication and repair, and chromatin determination [28]. In the present study, Cd significantly inhibited DNA methyltransferase in Dong17 but showed no change in Weisuobuzhi, which represented a 2.6-fold higher relative expression of this gene in Weisuobuzhi (Additional file 6: Table S5). In addition, $\mathrm{Cd}$ stress induced a marked increase in DNA damage to the $\mathrm{Cd}$-sensitive genotype Dong17 (Figure 6). Phytochelatins are widely accepted as a major agent of plant detoxification and tolerance to Cd stress [7] and a lack of PC synthase activity resulted in an increased sensitivity to Cd [29]. Our previous research has shown that genotypic differences in $\mathrm{Cd}$ tolerance were positively linked to the elevation of PCs in rice [30]. In this study, transcripts of PC synthase were significantly inhibited in Dong17, while no change was found in Weisuobuzhi (Additional file 6: Table S5). In summary, the results demonstrated that Cd-tolerant Weisuobuzhi is more capable to scavenge Cd-induced ROS by increasing the activity of antioxidant enzymes, to maintain DNA structural stability and protect the normal DNA methylation, and to sequester more $\mathrm{Cd}^{2+}$ to vacuole to reduce $\mathrm{Cd}$ toxicity.

\section{Membrane transport genes modulate ion homeostasis for Cd tolerance}

$\mathrm{Cd}$ affects the distribution of nitrogen, but nitrogen could be recycled and be translocated as a Cd protection and storage strategy [31]. Li et al. [32] reported that nitrate transporter NRT1.8-regulated nitrate distribution plays an important role in $\mathrm{Cd}$ tolerance. In addition, inwardly rectifying $\mathrm{K}^{+}$channels (IRK) contributes to cellular $\mathrm{K}^{+}$homeostasis in higher plants [33]. In the present study, the genes encoding transporters for nitrogen (NRaT and NRiT) and potassium (IRK) were significantly decreased in Dong17 but remained unchanged in Weisuobuzhi (Additional file 6: Table S5). Cd stress also induced a significant decrease of $\mathrm{K}^{+}$content in Dong17 but no change in Weisuobuzhi (Table 2), indicating a role for IRK in the reduced $\mathrm{K}^{+}$uptake in Dong17. Moreover, $\mathrm{ABC}$ transporters are involved in the homeostasis of organic anions, heavy metals, xenobiotics and lipids [34], including vacuolar compartmentalisation of Cd [35]. The ABC transporters of Arabidopsis, AtMRP3 and AtATM3, have been shown to confer Cd resistance [35,36]. AtPDR8 is a Cd extrusion pump conferring $\mathrm{Cd}$ and $\mathrm{Pb}$ resistance [34]. However, the genes encoding $\mathrm{ABC}$ transporters, in this study, were significantly inhibited in Dong17 while not affected in Weisuobuzhi (Additional file 6: Table S5). Therefore, a higher $\mathrm{Cd}$ accumulation in Weisuobuzhi (Figure 1) did not affect its overall Cd tolerance, but rather supported the hypothesis that more Cd is transported into the vacuoles of Weisuobuzhi, alleviating $\mathrm{Cd}$ toxicity to the cytoplasm.
As a result, these data enable us to generate a specific model on key components of vacuolar compartmentalisation for $\mathrm{Cd}$ tolerance (Additional file 13: Figure S3). Interestingly, ten key genes found to be down-regulated in the Cd-sensitive Dong17, were unchanged in Weisuobuzhi. All these highlighted that the high $\mathrm{Cd}$ accumulation in Weisuobuzhi (Figure 1; Chen et al. [1]) is linked with expression patterns of those specific genes involved in vacuolar compartmentalization, which is one of the most crucial strategies for Cd tolerance in plants.

\section{Hormonal and $\mathrm{Ca}^{2+}$ signal transduction related genes are important for Cd tolerance}

Phytohormones such as SA, JA and ET play fundamental roles via signalling crosstalk in abiotic stresses in plants [37]. For instance, Cd stress triggered an accumulation of ET in bean [38]. It has also been suggested that ET signalling pathways affect the early phase of $\mathrm{Cd}$ stress response, and 1-aminocyclopropane-1-carboxylic acid oxidase (ACO) catalyses the last step of ET biosynthesis in Arabidopsis [14]. Transcripts of ACO was markedly increased in Weisuobuzhi but was no change in Dong17 (Additional file 5: Table S4). ET activates stress-responsive genes in the hormonal signalling cascade against $\mathrm{Cd}$ toxicity. However, transcripts of ET-induced proteins were all significantly decreased in Dong17 (Additional file 6: Table S5). Cd-induced ET emission was also lower in Dong17 compared to that in Weisuobuzhi, which was consistent with the transcripts of ACO (Table 1; Additional file 5: Table S4). These results may suggest that Weisuobuzhi is more likely to defend itself against $\mathrm{Cd}$ stress through ET signalling. Meanwhile, $\mathrm{Ca}^{2+}$-binding protein calmodulin (CAM) transduces second messenger signals into a wide range of cellular responses [39]. Accumulation of $\mathrm{Cd}^{2+}$ may compete with cellular $\mathrm{Ca}^{2+}$ for CAM binding sites [40]. Under Cd stress, there was significantly less leaf $\mathrm{Ca}^{2+}$ in Dong17 than that in Weisuobuzhi (Table 2). Our results showed that $\mathrm{Cd}$ induces more signal molecules and activate $\mathrm{Cd}$ responsive genes more rapidly in Cd-tolerant Weisuobuzhi than those in Dong17. This difference again contributes to the high Cd-tolerance of Weisuobuzhi.

\section{Carbohydrate metabolism related genes regulate cell wall structure for Cd tolerance}

Cell wall, consisting of cellulose, hemicelluloses and pectin, which contain carboxyl, hydroxyl and aldehyde, can sequester a substantial amount of Cd under Cd stress [5]. For instance, Cosio et al. [41] found Cd binding in leaf cell wall could play a major role in Cd tolerance and hyperaccumulation in Thlaspi caerulescens and Arabidopsis halleri. Xiong et al. [42] found that $200 \mu \mathrm{M}$ Cd markedly decreased the pectin and hemicellulose content in rice root cell wall. Glycosyl hydrolases $(\mathrm{GH})$ are also 
essential for the modification of cell wall polysaccharides [43]. In the present study, GH and GT were found to be down-regulated in Dong17, but showed no change in Weisuobuzhi. Hence, Weisuobuzhi could maintain normal cell wall synthesis, remodelling and modification, and consequently have the capacity to accumulate much higher $\mathrm{Cd}$ at the cell wall (Figure 1), therefore reducing $\mathrm{Cd}$ toxicity to the cytoplasm.

\section{Defence and DNA replication related genes are critical for Cd tolerance}

Chitinases are components of plant defences against high concentrations of heavy metals such as $\mathrm{Cd}$ and As [44]. Chitinase 2 genes showed significant up-regulation under Cd stress in Weisuobuzhi (Additional file 5: Table S4), which was confirmed by the elevated chitinase activity (Table 1). Moreover, Cd affects cell cycle progression, differentiation, DNA replication and repair [45]. Histones such as H2B may be able to repair heavy metal-induced DNA damage in plant cells $[46,47]$. In the current study, transcripts of $\mathrm{H} 2 \mathrm{~A}, \mathrm{H} 2 \mathrm{~B}, \mathrm{H} 3$ and $\mathrm{H} 4$ were all significantly down-regulated in Dong17 but were not modified in Weisuobuzhi (Additional file 6: Table S5). Also, genes encoding DNA replication related proteins (e.g. DNA binding protein, polymerase and origin recognition complex subunit 4) were all significantly inhibited in Dong17 under Cd stress, while no change was found in Weisuobuzhi (Additional file 6: Table S5). Considering the significant $\mathrm{Cd}$-induced DNA damage found in Dong 17 (Figure 6), we thus suggest that defence and DNA replication related proteins like Chitinases and histones could be key determinants for $\mathrm{Cd}$ tolerance in barley.

\section{Cd-responsive miRNAs showed a negative link to the expression of key genes in this study}

miRNAs are a large family of small non-coding RNAs that negatively regulate mRNA at the post-transcriptional level [48]. Establishing a link between published miRNAs in the literature and our microarray data could provide a better understanding and validation to further investigate the key genes in $\mathrm{Cd}$ tolerance in plants. We identified 13 genes, showed significant negative correlation $\left(\mathrm{r}^{2}=0.441\right.$; $P<0.001$ ) between the microarray data (Additional file 14: Table S11) and different miRNA families [48-51]. The results demonstrated combination of microarray and miRNA analysis could narrow down the number of candidate genes conferring $\mathrm{Cd}$ tolerance from thousands to tens, providing a promising outlook for future functional analysis of these genes.

\section{Conclusions}

The use of genome-wide transcriptome analysis highlights novel integrated molecular mechanisms associated with Cd-tolerance. Our results are potentially important for the characterisation of molecular mechanisms underlying $\mathrm{Cd}$ tolerance in barley. We demonstrated that Cd-tolerant Weisuobuzhi (1) is more capable to scavenge Cd-induced ROS; (2) is able to maintain ion homeostasis and sequester more $\mathrm{Cd}$ into the vacuoles via the $\mathrm{ABC}$ transporters and ATPase; (3) has higher efficiency in ET and $\mathrm{Ca}^{2+}$ signal transduction; (4) maintains normal cell wall function; and (5) expresses defence and DNA replication related proteins for $\mathrm{Cd}$ tolerance in barley. These distinct differences in gene expression profiles, biochemical and physiological functions between $\mathrm{Cd}$-tolerant and -sensitive genotypes will provide critical information for extending our knowledge and guiding our future investigations into the candidate genes and proteins underlying $\mathrm{Cd}$ tolerance in barley.

\section{Additional files}

Additional file 1: Table S1. Name of genes and their primers used in quantitative RT-PCR.

Additional file 2: Figure S1. Leaf transcriptome profiles of $\mathrm{Cd}$ stress-responsive genes in barley leaves.

Additional file 3: Table S2. Summary of groups and numbers of differentially expressed genes between Cd-treated and control in leaves of two barley genotypes after exposure to $5 \mu \mathrm{M} C d$ for $15 \mathrm{~d}$.

Additional file 4: Table S3. List of genes up-regulated in Weisuobuzhi and down-regulated in Dong17 after exposing the plants to $5 \mu \mathrm{M} \mathrm{Cd}$ for $15 \mathrm{~d}$.

Additional file 5: Table S4. List of genes up-regulated in Weisuobuzhi and not changed in Dong17 after exposing the plants to $5 \mu \mathrm{M} \mathrm{Cd}$ for $15 \mathrm{~d}$.

Additional file 6: Table S5. List of genes not changed in Weisuobuzhi and down-regulated in Dong17 after exposing the plants to $5 \mu \mathrm{M} \mathrm{Cd}$ for $15 \mathrm{~d}$.

Additional file 7: Table S6. List of genes up-regulated in both Weisuobuzhi and Dong17 after exposing the plants to $5 \mu \mathrm{M} \mathrm{Cd}$ for $15 \mathrm{~d}$. Additional file 8: Table S7. List of genes down-regulated in Weisuobuzhi and up-regulated in Dong17 after exposing the plants to $5 \mu \mathrm{M}$ Cd for $15 \mathrm{~d}$.

Additional file 9: Table S8. List of genes down-regulated in both Weisuobuzhi and Dong 17 after exposing the plants to $5 \mu \mathrm{M} \mathrm{Cd}$ for $15 \mathrm{~d}$. Additional file 10: Table S9. List of genes down-regulated in Weisuobuzhi and not changed in Dong17 after exposing the plants to $5 \mu \mathrm{M}$ Cd for $15 \mathrm{~d}$.

Additional file 11: Table S10. List of genes not changed in Weisuobuzhi and up-regulated Dong17 after exposing the plants to $5 \mu \mathrm{M}$ Cd for $15 \mathrm{~d}$.

Additional file 12: Figure S2. Functional categorisation and differential expression of $\mathrm{Cd}$ stress-regulated genes in barley leaves.

Additional file 13: Figure S3. Integrated schematic diagram of the mechanisms involved in vacuolar compartmentalization of $\mathrm{Cd}$ in barley leaves.

Additional file 14: Table S11. Links between the novel Cd-responsive genes in barley leaves from this study and Cd-responsive miRNAs and their putative targets from the literature.

\section{Competing interests}

The authors declare that they have no competing interests. 


\section{Authors' contributions}

FBC, HS, and FC carried out the molecular and physiological studies. FBC, $\mathrm{ZHC}$ and FW drafted the manuscript. FBC, GZ, ZHC, and FW participated in the design of the study and performed the statistical analysis. GZ, FW conceived the study and participated in its design and coordination. All authors read and approved the final manuscript.

\section{Acknowledgements}

This project was funded by National Natural Science Foundation of China (30571097, 31071365), the National 863 program (2012AA101105), the Ph.D. Programs Foundation of Ministry of Education of China (20110101110088), and the Key Research Foundation of Science and Technology Department of Zhejiang Province of China (2012C12902-2). Z.H.C. is supported by a Research Lectureship of University of Western Sydney and a Discovery Early Career Researcher Award (DE140101143) of the Australian Research Council. We deeply appreciate Ms Mei Li from 985-Institute of Agrobiology and Environmental Science (985-IAES) of Zhejiang University, for her kind help with the experiment.

\section{Received: 25 April 2014 Accepted: 14 July 2014}

Published: 19 July 2014

\section{References}

1. Chen F, Wang F, Zhang GP, Wu FB: Identification of barley varieties tolerant to cadmium toxicity. Biol Trace Elem Res 2008, 121:171-179.

2. Uraguchi S, Fujiwara T: Cadmium transport and tolerance in rice: perspectives for reducing grain cadmium accumulation. Rice 2012, 5:5.

3. Wu FB, Zhang GP, Dominy P: Four barley genotypes respond differently to cadmium: lipid peroxidation and activities of antioxidant capacity. Environ Exp Bot 2003, 50:67-78.

4. Clijsters H, Vanassche FV: Inhibition of photosynthesis by metals. Photosynth Res 1985, 7:31-40

5. Wu FB, Dong J, Qian QQ, Zhang G: Subcellular distribution and chemical form of $\mathrm{Cd}$ and $\mathrm{Cd}-\mathrm{Zn}$ interaction in different barley genotypes. Chemosphere 2005, 60:1437-1446.

6. Hall JL: Cellular mechanisms for heavy metal detoxification and tolerance. J Exp Bot 2002, 53:1-11.

7. Cobbett CS: Phytochelatins and their roles in heavy metal detoxification Plant Physiol 2000, 123:825-832.

8. Courbot M, Willems G, Motte P, Arvidsson S, Roosens N, Saumitou-Laprade $P$, Verbruggen $\mathrm{N}$ : A major quantitative trait locus for cadmium tolerance in Arabidopsis halleri colocalizes with HMA4, a gene encoding a heavy metal ATPase. Plant Physiol 2007, 144:1052-1065.

9. Zhao CR, Ikka T, Sawaki Y, Kobayashi Y, Suzuki Y, Hibino T, Sato S, Sakurai N, Shibata D, Koyama H: Comparative transcriptomic characterization of aluminum, sodium chloride, cadmium and copper rhizotoxicities in Arabidopsis thaliana. BMC Plant Biol 2009, 9:32.

10. Villiers F, Ducruix C, Hugouvieux V, Jarno N, Ezan E, Garin J, Junot C, Bourguignon J: Investigating the plant response to cadmium exposure by proteomic and metabolomic approaches. Proteomics 2011, 11:1650-1663.

11. Rabbani MA, Maruyama K, Abe H, Khan MA, Katsura K, Ito Y, Yoshiwara K, Seki M, Shinozaki K, Yamaguchi-Shinozaki K: Monitoring expression profiles of rice genes under cold, drought, and high-salinity stresses and abscisic acid application using CDNA microarray and RNA gel-blot analyses. Plant Physiol 2003, 133:1755-1767.

12. Sasidharan R, Mustroph A, Boonman A, Akman M, Ammerlaan AMH, Breit T, Schranz ME, Voesenek LACJ, van Tienderen PH: Root transcript profiling of two Rorippa species reveals gene clusters associated with extreme submergence tolerance. Plant Physiol 2013, 163:1277-1292.

13. Bovet $L$, Feller $U$, Martinoia E: Possible involvement of plant $A B C$ transporters in cadmium detoxification: a cDNA sub-microarray approach. Environ Int 2005, 31:263-267.

14. Herbette S, Taconnat L, Hugouvieux V, Piette L, Magniette ML, Cuine S, Auroy P, Richaud P, Forestier C, Bourguignon J, Renou JP, Vavasseur A, Leonhardt N: Genome-wide transcriptome profiling of the early cadmium response of Arabidopsis roots and shoots. Biochimie 2006, 88:1751-1765.

15. Kramer U: Metal hyperaccumulation in plants. Annu Rev Plant Biol 2010, 61:517-534.

16. Mendoza-Cózatl DG, Jobe TO, Hauser F, Schroeder Jl: Long distance transport, vacuolar sequestration, tolerance, and transcriptional responses induced by cadmium and arsenic. Curr Opin Plant Biol 2011, 14:554-562.

17. Ullrich SE (Ed): Barley: Production, Improvement, and Uses. New Jersey: WileyBlackwell; 2010

18. Chen F, Wang F, Wu FB, Mao WH, Zhang GP, Zhou MX: Modulation of exogenous glutathione in antioxidant defense system against $\mathrm{Cd}$ stress in the two barley genotypes differing in Cd tolerance. Plant Physiol Bioch 2010, 45:663-672.

19. Chen F, Wang F, Sun HY, Cai Y, Mao WH, Zhang GP, Vincze E, Wu FB: Genotype-dependent effect of exogenous nitric oxide on $\mathrm{Cd}$-induced changes in antioxidative metabolism, ultrastructure, and photosynthetic performance in barley seedlings (Hordeum vulgare). J Plant Growth Regul 2010, 29:394-408.

20. Irizarry RA, Hobbs B, Collin F, Beazer-Barclay, Antonellis KJ, Scherf U, Speed TP: Exploration, normalization, and summaries of high density oligonucleotide array probe level data. Biostatistics 2003, 4:249-264.

21. Menke M, Chen IP, Angelis KJ, Schubert I: DNA damage and repair in Arabidopsis thaliana as measured by the comet assay after treatment with different classes of genotoxins. Mutat Res 2001, 493:87-93.

22. Chen L, Dodd IC, Davies WJ, Wilkinson S: Ethylene limits abscisic acid- or soil drying-induced stomatal closure in aged wheat leaves. Plant Cell Environ 2013, 36:1850-1859.

23. Rodriguez-Serrano M, Romero-Puertas MC, Zabalza A, Corpas FJ, Gomez M, Del Rio LA, Sandalio LM: Cadmium effect on oxidative metabolism of pea (Pisum sativum L.) roots. Imaging of reactive oxygen species and nitric oxide accumulation in vivo. Plan Cell Environ 2006, 29:1532-1544.

24. Roxas VP, Lodhi SA, Garrett DK, Mahan JR, Allen RD: Stress tolerance in transgenic tobacco seedlings that overexpress glutathione S-transferase/ glutathione peroxidase. Plant Cell Physiol 2000, 41:1229-1234.

25. Serrano R: Structure and function of plasma membrane ATPase. Annu Rev Plant Biol 1989, 40:61-94

26. Williams LE, Mills RF: $P_{1 B}$-ATPases - an ancient family of transition metal pumps with diverse functions in plants. Trends Plant Sci 2005, 10:491-502.

27. Dietz KJ, Tavakoli N, Kluge C, Mimura T, Sharma SS, Harris GC, Chardonnens AN, Golldack D: Significance of the V-type ATPase for the adaptation to stressful growth conditions and its regulation on the molecular and biochemical level. J Exp Bot 2001, 52:1969-1980.

28. Finnegan EJ, Peacock WJ, Dennis ES: Reduced DNA methylation in Arabidopsis thaliana results in abnormal plant development. Proc Natl Acad Sci U S A 1996, 93:8449-8454.

29. Fusco N, Micheletto L, Corso GD, Borgato L, Furini A: Identification of cadmium-regulated genes by CDNA-AFLP in the heavy metal accumulator Brassica juncea L. J Exp Bot 2005, 56:3017-3027.

30. Cai Y, Cao FB, Cheng WD, Zhang GP, Wu FB: Modulation of exogenous glutathione in phytochelatins and photosynthetic performance against $\mathrm{Cd}$ stress in the two rice genotypes differing in $\mathrm{Cd}$ tolerance. Biol Trace Elem Res 2011, 143:1159-1173.

31. Chaffei C, Pageau K, Suzuki A, Gouia H, Ghorbel MH, Masclaux-Daubresse C: Cadmium toxicity induced changes in nitrogen management in Lycopersicon esculentum leading to a metabolic safeguard through an amino acid storage strategy. Plant Cell Physiol 2004, 45:1681-1693.

32. Li JY, Fu YL, Pike SM, Bao J, Tian W, Chen CZ, Zhang Y, Li HM, Huang J, Li LG, Schroeder Jl, Gassmann W, Gong JM: The Arabidopsis nitrate transporter NRT1.8 functions in nitrate removal from the xylem sap and mediates cadmium tolerance. Plant Cell 2010, 22:1633-1646.

33. Schachtman DP, Schroeder JI, Lucas WJ, Anderson JA, Gaber RF: Expression of an inward-rectifying potassium channel by the Arabidopsis KAT1 cDNA. Science 1992, 258:1654-1658.

34. Kim DY, Bovet $L$, Maeshima M, Martinoia $E$, Lee $Y$ : The $A B C$ transporter AtPDR8 is a cadmium extrusion pump conferring heavy metal resistance. Plant J 2007, 50:207-218

35. Bovet L, Eggmann T, Meylan-Bettex M, Polier J, Kammer P, Marin E, Feller U, Martinoia E: Transcript levels of AtMRPs after cadmium treatment: induction of AtMRP3. Plant Cell Environ 2003, 26:371-381.

36. Kim DY, Bovet L, Kushnir S, Noh EW, Martinoia E, Lee Y: AtATM3 is involved in heavy metal resistance in Arabidopsis. Plant Physiol 2006, 140:922-932.

37. Fujita M, Fujita Y, Noutoshi Y, Takahashi F, Narusaka Y, Yamaguchi-Shinozaki K, Shinozaki K: Crosstalk between abiotic and biotic stress responses: a current view from the points of convergence in the stress signaling networks. Curr Opin Plant Biol 2006, 9:436-442. 
38. Fuhrer J: Ethylene biosynthesis and cadmium toxicity in leaf tissue of beans (Phaseolus vulgaris L.). Plant Physiol 1982, 70:162-167.

39. Zielinski RE: Calmodulin and calmodulin-binding proteins in plants. Annu Rev Plant Biol 1998, 49:697-725.

40. Garnier L, Simon-Plas F, Thuleau P, Agnel JP, Blein JP, Ranjeva R, Montillet JL: Cadmium affects tobacco cells by a series of three waves of reactive oxygen species that contribute to cytotoxicity. Plant Cell Environ 2006, 29:1956-1969.

41. Cosio C, Martinnoia E, Keller C: Hyperaccumulation of cadmium and zinc in Thlaspi caerulescens and Arabidopsis halleri at the leaf cellular level. Plant Physiol 2004, 134:716-725.

42. Xiong J, An LY, Lu H, Zhu C: Exogenous nitric oxide enhances cadmium tolerance of rice by increasing pectin and hemicellulose contents in root cell wall. Planta 2009, 230:755-765.

43. Lee EJ, Matsumura Y, Soga K, Hoson T, Koizumi N: Glycosyl hydrolases of cell wall are induced by sugar starvation in Arabidopsis. Plant Cell Physiol 2007, 48:405-413.

44. Békésiová B, Hraška Š, Libantová J, Moravčíková J, Matušíková I: Heavy-metal stress induced accumulation of chitinase isoforms in plants. Mol Biol Rep 2008, 35:579-588.

45. Bertin G, Averbeck D: Cadmium: cellular effects, modifications of biomolecules, modulation of DNA repair and genotoxic consequences (a review). Biochimie 2006, 88:1549-1559.

46. Jenuwein T, Allis CD: Translating the histone code. Science 2001, 293:1074-1080.

47. Sobkowiak R, Deckert J: Proteins induced by cadmium in soybean cells. J Plant Physiol 2006, 163:1203-1206.

48. Ding YF, Chen Z, Zhu C: Microarray-based analysis of cadmium-responsive microRNAs in rice (Oryza sativa). J Exp Bot 2011, 60:3563-3573.

49. Zhou ZS, Song JB, Yang ZM: Genome-wide identification of Brassica napus microRNAs and their targets in response to cadmium. J Exp Bot 2012, 63:4597-4613.

50. Huang SQ, Peng J, Qiu CX, Yang ZM: Heavy metal-regulated new microRNAs from rice. J Inorg Biochem 2009, 103:282-287.

51. Xu L, Wang Y, Zhai LL, Xu YY, Wang LJ, Zhu XW, Gong YQ, Yu RG, Limera C, Liu LW: Genome-wide identification and characterization of cadmiumresponsive microRNAs and their target genes in radish (Raphanus sativus $\mathrm{L}$.) roots. J Exp Bot 2013, 64:4271-4287.

doi:10.1186/1471-2164-15-611

Cite this article as: Cao et al: Genome-wide transcriptome and functional analysis of two contrasting genotypes reveals key genes for cadmium tolerance in barley. BMC Genomics 2014 15:611.

\section{Submit your next manuscript to BioMed Central and take full advantage of:}

- Convenient online submission

- Thorough peer review

- No space constraints or color figure charges

- Immediate publication on acceptance

- Inclusion in PubMed, CAS, Scopus and Google Scholar

- Research which is freely available for redistribution 